\title{
CARBON DIOXIDE OUTPUT AND ELIMINATION IN CHILDREN UNDER ANAESTHESIA
}

\author{
J.A. BAIN AND W.E. SPOEREL
}

\begin{abstract}
A modified Mapleson D type Gircuir with a coaxial fresh gas inflow line (Bain breathing circuit) has been used in our hospital for the past four years in all patients including children. ${ }^{1}$ In metabolically normal adult patients, a fresh gas inflow of $70 \mathrm{ml} / \mathrm{kg}$ was found adequate for carbon dioxide elimination and this has since been confirmed by others., ${ }^{2,3}$ We recommended not to reduce the total fresh gas flow below $3.5 \mathrm{l} / \mathrm{min}$ and to use this flow in all patients with a body weight below $50 \mathrm{~kg}$, regardless of age. ${ }^{4}$

The Mapleson D system is widely used in paediatric anaesthesia and Nightingale, et al..$^{5}$ have demonstrated that a total fresh gas flow of $31 / \mathrm{min}$ is adequate to eliminate carbon dioxide and indeed to induce hypocapnia in children under 30 pounds body weight.

We have re-examined the requirements of fresh gas inflow in children with our circuit in two ways:

1. The $\mathrm{Pa}_{\mathrm{CO}_{2}}$ was determined under controlled ventilation with a total fresh gas inflow of $3.5 \mathrm{I} / \mathrm{min}$.

2. The carbon dioxide output was estimated from the total fresh gas inflow and the mixed expired carbon dioxide concentration as described in a previous publication $^{6}$ in children breathing spontaneously and on controlled ventilation.
\end{abstract}

\section{Method of Study and Results}

1. Arterial carbon dioxide tension $\left(\mathrm{Pa}_{\mathrm{CO}_{2}}\right):$ In 46 children, ranging from newborn to 16 years of age, arterial blood samples were taken about one hour after induction of anaesthesia with halothane or enflurane and nitrous oxide-oxygen. The children were all normal from a cardiopulmonary and metabolic point of view and were undergoing routine surgical procedures. Precautions were taken to avoid marked changes in body temperature. From the start of the anaesthetic the total fresh gas flow was kept constant at $3.5 \mathrm{l} / \mathrm{min}$. Ventilation was controlled with a tidal volume set at about $10 \mathrm{ml} / \mathrm{kg}$.

The $\mathrm{PaCO}_{2}$ values obtained are presented in Figure 1. Since fresh gas flow rates are usually related to body weight in the anaesthetic literature, we have grouped our patients according to weight. As expected, the lowest carbon dioxide tension was seen in the weight group under $10 \mathrm{~kg}$ and the $\mathrm{Pa}_{\mathrm{CO}_{2}}$ increased with increasing body weight. Up to the weight group of 30 to $40 \mathrm{~kg}$ the $\mathrm{Pa}_{\mathrm{CO}_{2}}$ was below 40 torr $(5.32 \mathrm{kPa})$ indicating that fresh gas inflow and ventilation provided for adequate

J.A. Bain, M.D., F.R.C.P.(C), and W.E. Spoerel, M.D., F.R.C.P.(C), Department of Anaesthesia, University of Western Ontario, Victoria Hospital and University Hospital, London, Ontario N6A 4G5 


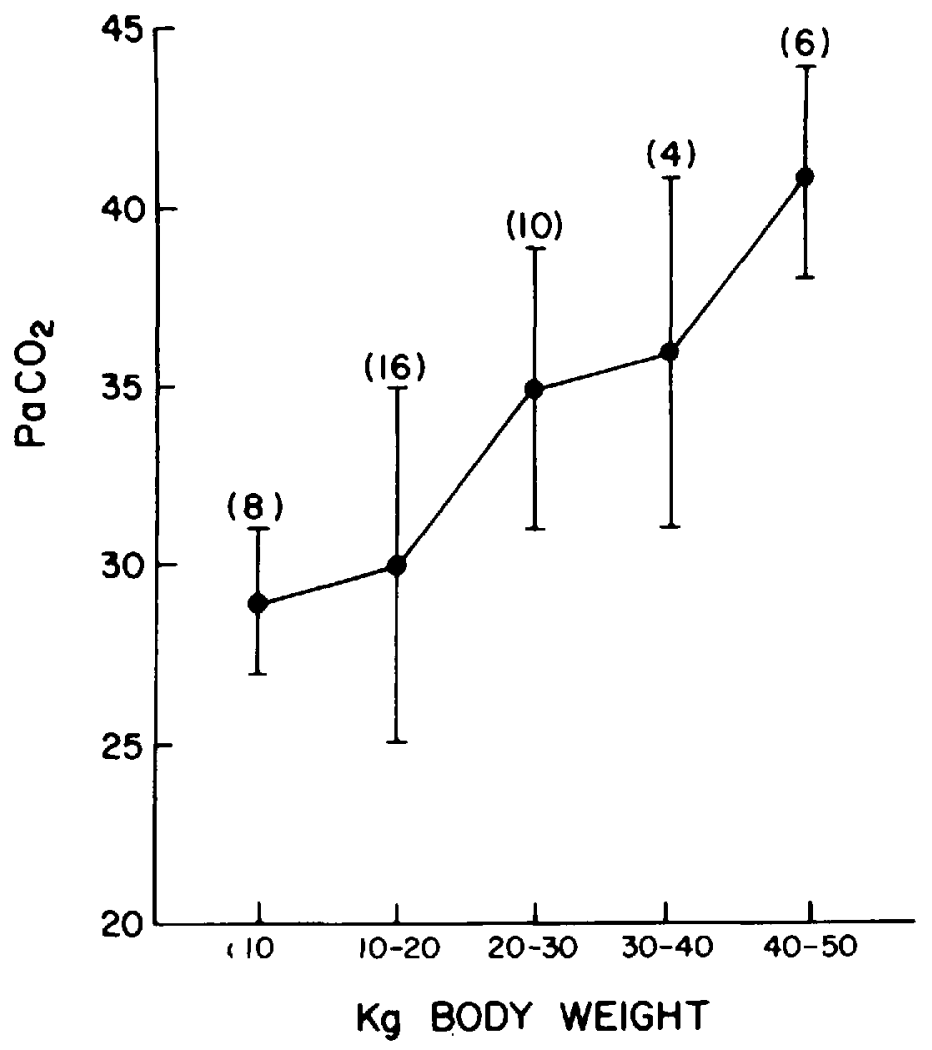

Ficure 1. Paro. in 44 children on controlled ventilation with a fresh gas flow of $3.5 \mathrm{l} / \mathrm{min}$.

carbon dioxide removal. Values about 40 torr $(5.32 \mathrm{kPa})$ were only encountered with a body weight above $40 \mathrm{~kg}$.

2. Carbon dioxide output: In a previous communication, ${ }^{6}$ we could show that the gas vented from the circuit has a virtually constant carbon dioxide concentration, thus representing a mixed expired carbon dioxide. If the volume of fresh gas inflow is kept constant, the volume of vented gas should be about equal to the volume of inflowing gas, once the initial uptake of anaesthetic agents has passed. An estimate of the patient's carbon dioxide output can thus be obtained by multiplying the volume of fresh gas inflow, as indicated on the flowmeters, by the volumes percent carbon dioxide measured in the gas vented from the circuit.

Determinations of the carbon dioxide output were done in 83 children, ranging from newborn to 16 years of age, all free from cardiopulmonary or metabolic conditions and anaesthetized with halothane or enflurane and nitrous oxideoxygen for routine surgical procedures. In 34 children the respiration was controlled, using a tidal volume of approximately $10 \mathrm{ml} / \mathrm{kg}$; the remainder of the patients were breathing spontaneously. The total fresh gas inflow was set at 3.0 or $3.5 \mathrm{l} / \mathrm{min}$ and kept constant throughout the anaesthetic; in children over $40 \mathrm{~kg}$ body weight, a calculated fresh gas flow of $100 \mathrm{ml} / \mathrm{kg} / \mathrm{min}$ was used. In children on controlled ventilation repeated measurements of the carbon dioxide output 


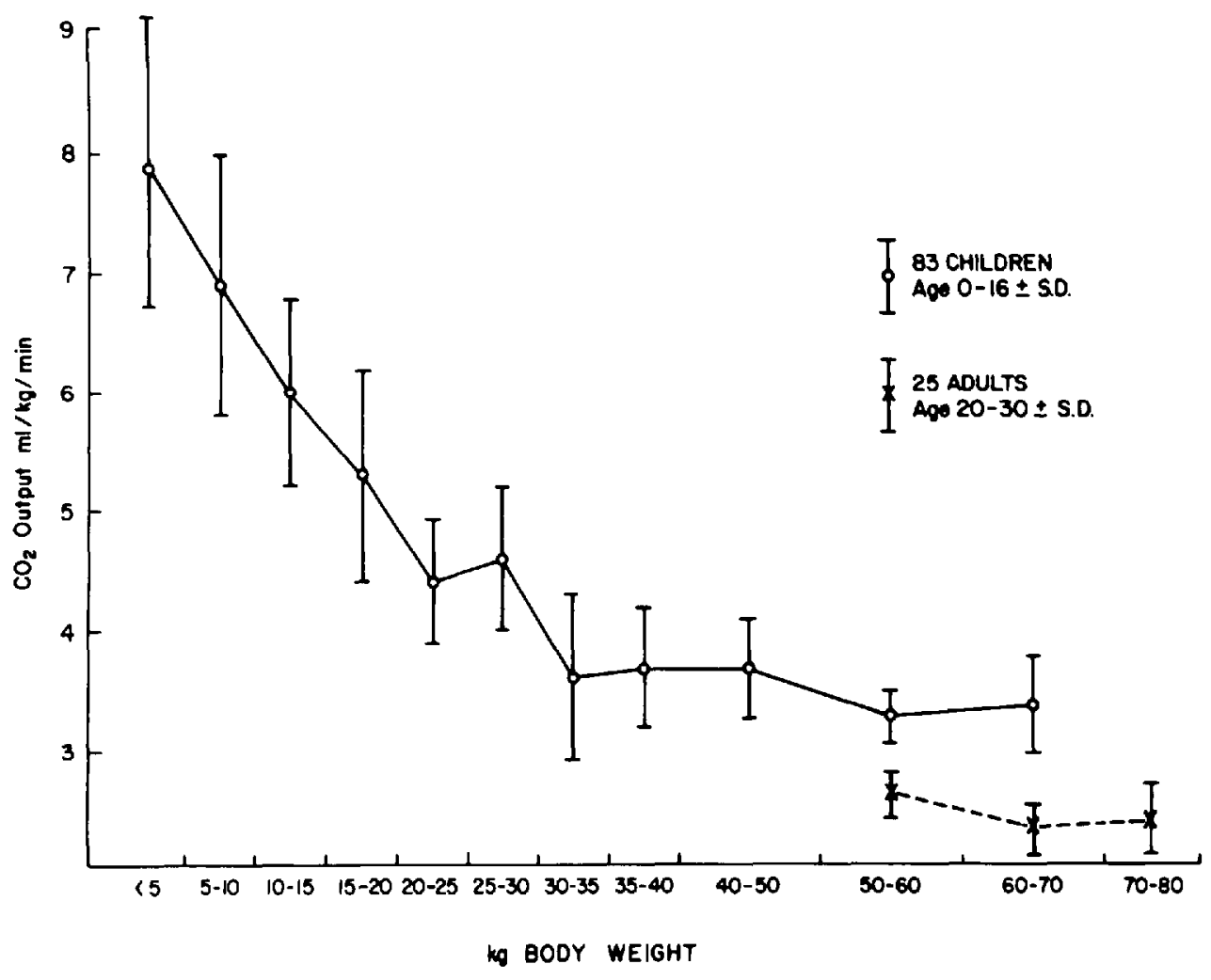

Ficune 2. Carbon dioxide output in $\mathrm{ml} / \mathrm{kg} / \mathrm{min}$ in 83 children (age 1 week to 16 years). Fol comparison the carbon dioxide output related to body weight is presented for 23 patients (age 20-30 years).

using a capnograph were done about 45 minutes to one hour after induction of anaesthesia. In spontaneously breathing patients values were obtained at fiveminute intervals between 30 and 60 minutes of anaesthesia in order to compensate for some variations in carbon dioxide output due to fluctuations in the patient's breathing. A mean value from these measurements was taken as representative. After reviewing our data, we decided for the purpose of this communication, not to separate the type of ventilation or the sexes; differences observed were not significant with the number of patients studied and were overshadowed by the considerable individual variations observed. We have related our results to body weight only and disregarded age. All measurements are expressed at BTPS.

As expected, the highest carbon dioxide output was found in the group up to $5 \mathrm{~kg}$ body weight at a mean value of $7.9 \mathrm{ml} / \mathrm{kg}$ (BTPS) (Figure 2). The carbon dioxide output declined with increasing weight up to the group of 30 to $35 \mathrm{~kg}$ body weight and remained at the same level in larger children. It should be noted that the carbon dioxide output in larger children in their 'teens was higher than that of adult patients in their twenties with the same body weight. A comparison of our data with measurements of basal metabolic rate in normal children by Lewis, et al. ${ }^{7}$ which were recalculated for carbon dioxide output based on the 


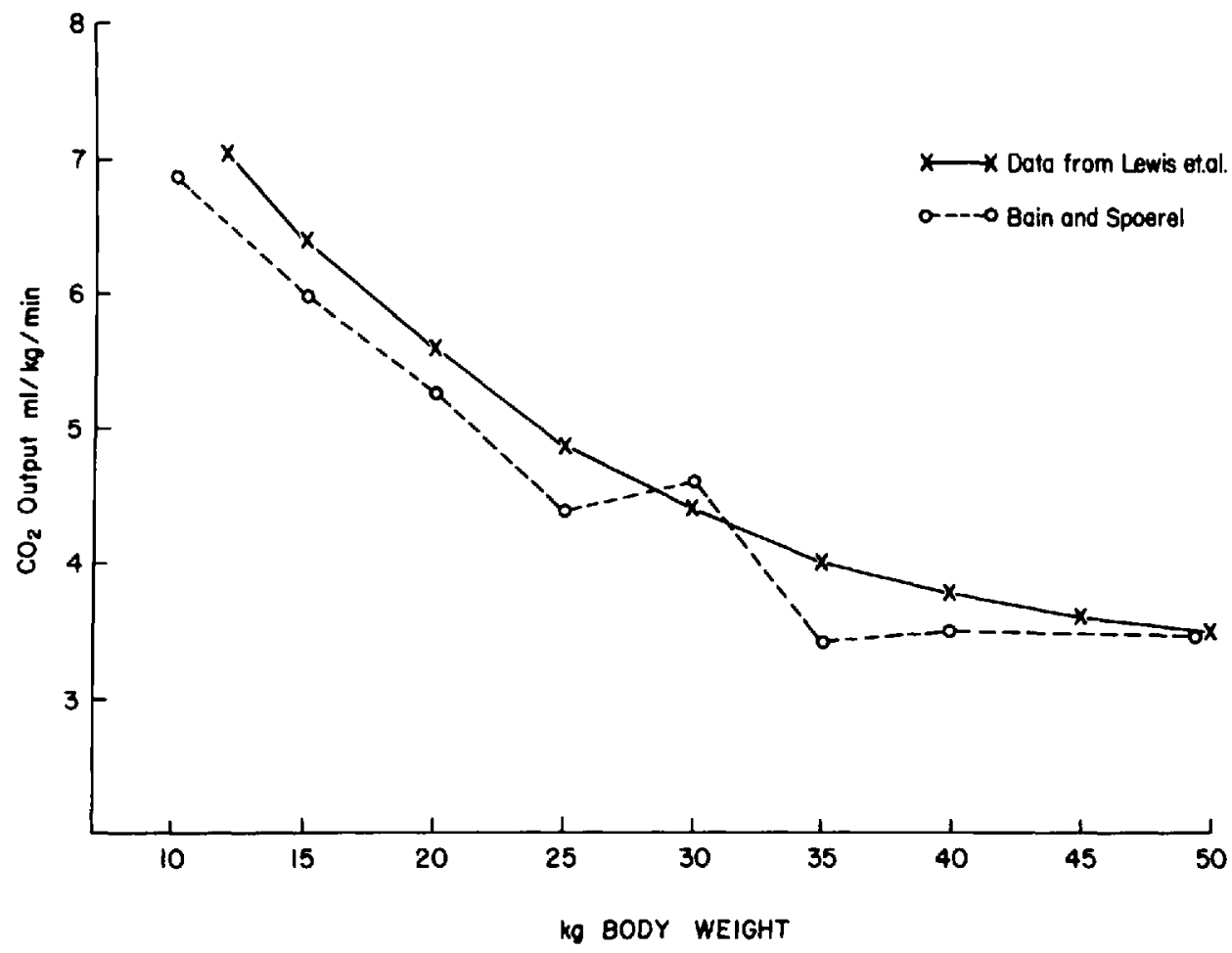

Figure 3. Carbon dioxide output (BTPS) related to body weight in children under anaesthesia $\left(0^{-}-O^{\circ}\right.$ compared to basal values in normal children calculated from Lewis, et al. $*$

formula proposed by Radford $\left(\mathrm{VCO}_{2}=2.778 \times \mathrm{Cal} /\right.$ hour $)$ showed a good agreement (Figure 3) and would indicate that the values obtained with our simple technique were of the appropriate order. In 15 of the spontaneously breathing children the $\mathrm{Pa}_{\mathrm{CO}_{2}}$ was determined during the same time that the carbon dioxide outputs were done. The mean arterial carbon dioxide tension was 39 torr (5.18 $\mathrm{kPa}$ ) with values ranging from 35 to 45 torr ( 4.65 to $5.98 \mathrm{kPa}$ ).

3. Requirement of fresh gas flow: In adult patients anaesthetized with a fresh gas flow of $70 \mathrm{ml} / \mathrm{kg}$, a mean carbon dioxide concentration of 3.4 per cent was measured in the gas vented from the circuit under conditions where a mean arterial $\mathrm{Pa}_{\mathrm{C}_{2}()_{2}}$ of about 37 torr $(4.92 \mathrm{kPa}$ ) was observed. Assuming that the same relationship would apply in children, we have calculated the fresh gas flow required to obtain a mixed expired carbon dioxide concentration of 3.4 per cent by dividing the carbon dioxide output by the carbon dioxide concentration in vented gas.

$$
\mathrm{VFG} \mathrm{ml} / \mathrm{kg} / \mathrm{min}=\frac{\mathrm{VCO}_{2} \mathrm{ml} / \mathrm{kg} / \mathrm{min}}{\text { Per cent carbon dioxide mixed expired gas }}
$$

The results of this exercise are presented in Figure 4. The scale for the fresh gas flow in $\mathrm{ml} / \mathrm{kg} / \mathrm{min}$ is on the right side of the graph; in children under $10 \mathrm{~kg}$ body weight, a fresh gas flow of over $200 \mathrm{ml} / \mathrm{kg} / \mathrm{min}$ is required and this require- 


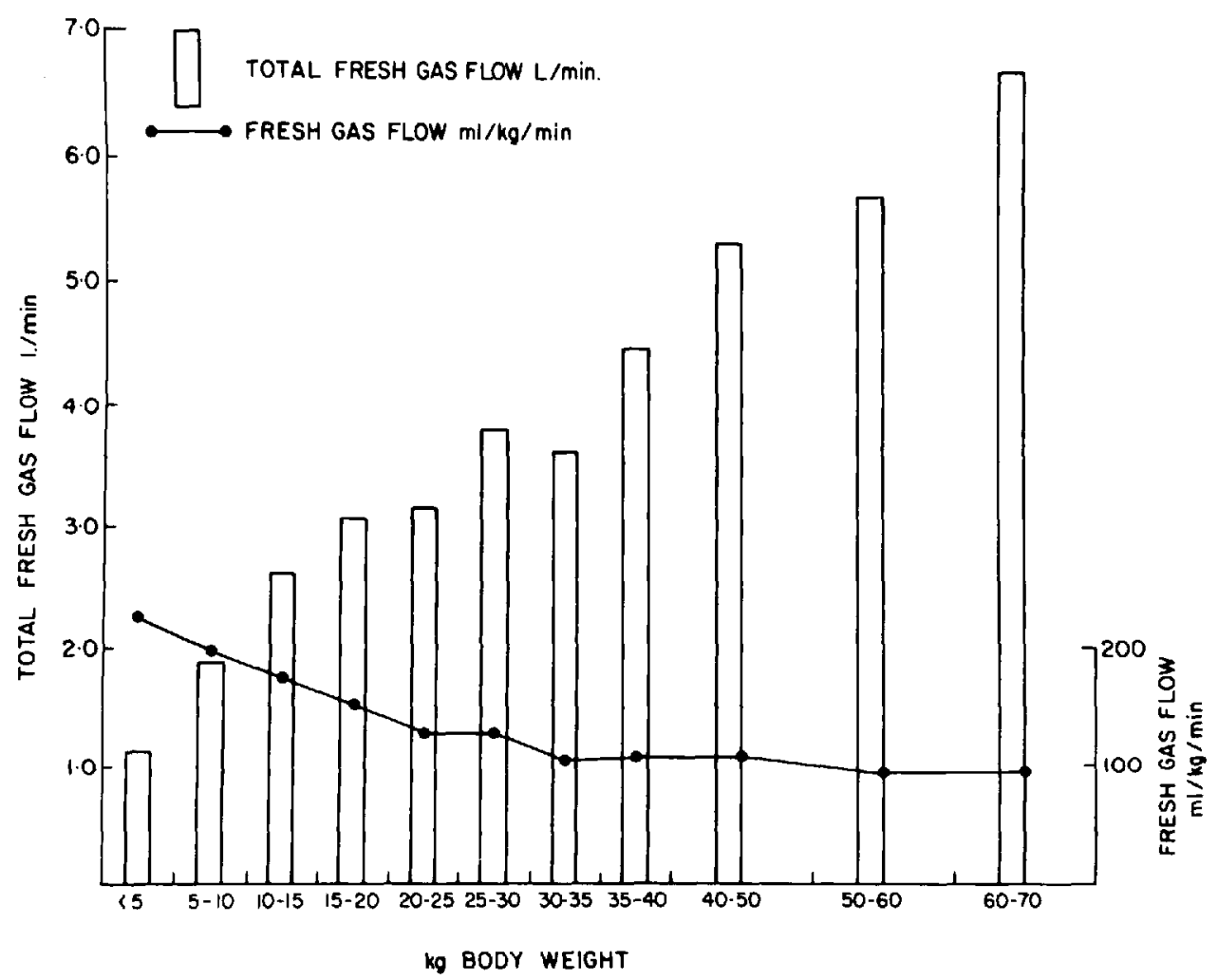

Figure 4. Requirements of fresh gas flow for adequate carbon dioxide elimination in children based on body weight in $\mathrm{ml} / \mathrm{kg} / \mathrm{min}$ (scale right side -required (scale left side $\Pi$ ).

ment falls to around $100 \mathrm{ml} / \mathrm{kg} / \mathrm{min}$ above $30 \mathrm{~kg}$ body weight. The total fresh gas flow required was also calculated and is represented by bars relating to the scale on the left of the graph. It is evident that a total fresh gas flow of 3.5 litres is adequate for patients up to $35 \mathrm{~kg}$ in body weight. In larger children, higher total flow rates would be required to maintain the $\mathrm{Pa}_{\mathrm{CO}_{2}}$ below 40 torr $(5.32 \mathrm{kPa}$ ) which was also demonstrated with the observation of values above 40 torr ( 5.32 $\mathrm{kPa}$ ) in children over $40 \mathrm{~kg}$ anaesthetized with a total fresh gas flow of 3.5 litres (Figure 1).

\section{CONCLUSION}

With measurements of the arterial carbon dioxide tension and the carbon dioxide output we have demonstrated that our original recommendation to use a total fresh gas inflow of $3.51 / \mathrm{min}$ in children provides for adequate carbon dioxide elimination up to $35 \mathrm{~kg}$ body weight. However, the use of a uniform flow rate over-compensates for the higher metabolic rate in small children and most children under $20 \mathrm{~kg}$ body weight were found to be mildly to moderately hypocarbic. Obviously the total fresh gas flow could be reduced below the recommended $3.5 \mathrm{l} / \mathrm{min}$. Rayburn and Graves ${ }^{3}$ have shown that at a basal metabolic state a 
minute ventilation of three times the alveolar ventilation and flow rates approximately equal to the alveolar ventilation appear sufficient to maintain a normal $\mathrm{Pa}_{\mathrm{Co}_{2}}$. In their opinion, much lower rates of fresh gas flow than have been recommended previously may be used safely.

The teenager, even though he has attained adult weight, has a metabolic rate higher than the adult and requires a higher fresh gas inflow.

According to our observations we have to modify our original recommendation ${ }^{4}$ to say that a total fresh gas inflow of $3.5 \mathrm{l} / \mathrm{min}$ is sufficient for children under 35 $\mathrm{kg}$ body weight. However, this over-compensates for the higher metabolic rate in small children on controlled ventilation, particularly those under $10 \mathrm{~kg}$ body weight. Our observations would support the view by Rayburn and Graves" that the fresh gas inflow could be reduced further, and our findings would indicate that in children under $10 \mathrm{~kg}$ body weight on controlled ventilation undue respiratory alkalosis could be avoided by a reduction of the total fresh gas flow to two litres per minute.

Since most anaesthetists prefer to err on the side of mild over-ventilation, and in view of the large variations in the metabolic rate of small children, we would hesitate to reduce the fresh gas inflow further, based on a calculated alveolar ventilation, unless the mixed expired carbon dioxide can be monitored. In children over $35 \mathrm{~kg}$ body weight a fresh gas inflow of $100 \mathrm{ml} / \mathrm{kg} / \mathrm{min}$ is required for adequate elimination of carbon dioxide during controlled ventilation and this includes teenage patients within the adult weight range.

\section{SUMMARY}

The requirements for fresh gas inflow with the Bain breathing circuit in children was examined by determining the $\mathrm{Pa}_{\mathrm{CO}_{2}}$ in 46 children during controlled ventilation with a total fresh gas inflow of $3.5 \mathrm{l} / \mathrm{min}$ and by measuring the carbon dioxide output in 83 children under anaesthesia. It could be shown that all children below $40 \mathrm{~kg}$ body weight had a $\mathrm{Pa}_{\mathrm{CO}_{2}}$ below 40 torr $\left(5.32 \mathrm{kPa}\right.$ ) and the $\mathrm{Pa}_{\mathrm{CO} 2}$ paralleled the body weight, i.e., the lowest carbon dioxide tension was seen in children under $10 \mathrm{~kg}$. As expected, the highest carbon dioxide output was found in children below $5 \mathrm{~kg}$ body weight; the carbon dioxide output per kilogram decreased with increasing body weight up to $30-35 \mathrm{~kg}$ and remained at that level in larger children. Children in their teens, although they may have attained adult body weight, had a higher carbon dioxide output than adults. Based on these findings, our recommendation of a total fresh gas inflow of $3.5 \mathrm{l} / \mathrm{mmin}$ for all children would appear adequate for a body weight up to $35 \mathrm{~kg}$ on controlled ventilation. In children under $10 \mathrm{~kg}$ body weight, a reduction of the total fresh gas flow to two litres per minute will avoid marked respiratory alkalosis. For children over $35 \mathrm{~kg}$, a fresh gas flow of $100 \mathrm{ml} / \mathrm{kg} / \mathrm{min}$ should be satisfactory during controlled ventilation.

\section{RÉSUMÉ}

Le volume-minute de gaz frais nécessaire chez l'enfant ventilé avec un circuit de Bain a été déterminé, premièrement, en étudiant la $\mathrm{Pa}_{\mathrm{CO}_{2}}$ de 46 enfants sous 
ventilation contrôlée et avec apport de 3.5 litres/minute de gaz frais et, deuxièmement, en déterminant la production de $\mathrm{CO}_{2}$ chez 83 enfants anesthésiés.

Dans ces conditions, nous avons observé que tous les enfants de moins de 40 kilos présentaient des $\mathrm{Pa}_{\mathrm{CO}_{2}}$ de moins de 40 torr, et que les $\mathrm{Pa}_{\mathrm{CO}_{2}}$ observées étaient fonction du poids: les $\mathrm{Pa}_{\mathrm{C}_{2}}$ les plus basses étant observées chez les petits de moins de 10 kilos.

Tel que prévu, la production maximale de $\mathrm{CO}_{2}$ a été observée chez les enfants de moins de 5 kilos. Elle diminuait ensuite jusqu'à un poids de 30 ou 35 kilos, alors qu'elle se stabilisait. Les adolescents, même ceux qui avaient atteint un poids adulte, maintenaient une production de $\mathrm{CO}_{2}$ supérieure à l'adulte.

Sur la base de ces observations, nous recommandons un apport minute de 3.5 litres de gaz frais chez l'enfant de 10 à 35 kilos. Chez le petit de moins de 10 kilos, nous recommandons un débit de 2 litres/minute. Enfin, $100 \mathrm{ml} / \mathrm{kilo}$ nous apparaissent adéquats chez l'enfant de plus de 35 kilos.

\section{REFERENCES}

1. Bain, J.A. \& Spoenel, W.E. A streamlined anaesthetic system. Canad. Anaesth. Soc. J, 19 : $426(1972)$.

2. Henville, J.D. \& Adams, A.P. The Bain anaesthetic system. Anaesthesia 31: 247 (1976).

3. ChU, Y.K., RaH, K.H., \& Boyan, C.P. Is the Bain breathing circuit the future anaesthesia system? Anaesth. \& Anal., Can. Res. 56: 84 (1977).

4. Bain, J.A. \& Spozhel, W.E. Flow requirements for a modified Mapleson D system during controlled ventilation. Canad. Anaes. Soc. J. 22: 34 (1973).

5. Nightincale, D.H., Richards, C.C., \& Glass, A. An evaluation of rebreathing in a modified T-piece system during controlled ventilation of anaesthetized children. Brit. J. Anaes. 37: 762 (1965)

6. Bain, J.A. \& Spoerel, W.E. Carbon dioxide output in anaesthesia. Canad. Anaes. Soc. J. 23: $153(1976)$.

7. Lewis, R.C., Duval, A.M., \& IlufF, A. Standards for basal metabolism. J. of Paed. 23: I (1943).

8. Radrond, E.P. Jr. Ventilation standards for use in artificial respiration. J. Appl. Physiol, $7: 451(1955)$.

9. Raybunn, R.L. \& Craves, S.A. Use of the Bain circuit anaesthetic system for children during controlled ventilation. Abstract - Meeting American Society of Anesthesiologists, 1976. 